\title{
OLFACTOMETRY DIAGNOSTIC AT THE MODERN STAGE
}

\author{
O. AVRUNIN ${ }^{l^{*}}$, N. SHUSHLYAPINA ${ }^{2}$, Y. NOSOVA ${ }^{1}$, O. BOGDAN $N^{3}$ \\ ${ }^{1}$ Department of Biomedical Engineering, Kharkiv National University of Radio Electronics, Kharkiv, UKRAINE \\ ${ }^{2}$ Department of Otorhinolaryngology, Kharkiv National Medical University, Kharkiv, UKRAINE \\ ${ }^{3}$ Department of Foreign languages, Kharkiv National University of Radio Electronics, Kharkiv, UKRAINE \\ *email: gavrun@list.ru
}

\begin{abstract}
In this article we consider the most popular methods for evaluating the degree of olfactory disorders. The purpose of our paper is an analytical review of olfactometry of methods and tools to determine their potential and the diagnostic value of the detection of respiratory-olfactory disorders (blocking of odorants getting into areas of the nasal mucosa, containing olfactory receptors). Purpusful study of olfactory function allows to determine the criteria for the diagnosis of local destruction of various parts of the analyze. Various methods and devices (olfactometers) are used to diagnose olfactory analyzer, but they all have a number of drawbacks: the long duration of the study, the use of objective evidence of the subjects, the use of olfactory substances that affect the end of the threefold nerve, determination of olfactory dysfunction or only quantitatively or only qualitatively. Most of the methods for evaluating of olfactory disorders have a wide range of uses for the diagnosis of various diseases as well, including mental disorders, brain damage, and nervous system. However, within our problem, olfactory dysfunction is necessary to consider in connection with the problem of the air passage in the human olfactory system. Therefore, it is necessary to develop a highly specialized method of assessing olfactory - respiratory disorders, which would have a high degree of objectivity for use in clinical practice of otolaryngologists. Thus, in the perspective of further research it seems necessary to develop a method of assessment of olfactory function on the basis of respiratory parameters derived from rinomanometry research that will improve the objectivity of conducted researches.
\end{abstract}

Keywords: smell, nose, olfactometry, mucous, odor, dysfunction, stimulus

\section{ОЛЬФАКТОМЕТРИЧЕСКАЯ ДИАГНОСТИКА НА СОВРЕМЕННОМ ЭТАПЕ}

\section{О. Г. АВРУНИН ${ }^{* *}$, Н. О. ШУШЛЯПИНА ${ }^{2}$, Я. В. НОСОВА ${ }^{1}$, О. Н. БОГДАН}

\author{
${ }^{1}$ Кафедра биомедичинской инженерии, Харьковский начиональный университет радиоэлектроники, Харьков, УКРАИНА \\ ${ }^{2}$ Кафедра Оториноларингологии, Харьковский начиональный медичинский университет, Харьков, УКРАИНА \\ ${ }^{3}$ Кафедра иностранных языков, Харьковский начиональный университет радиоэлектроники; Харьков, УКРАИНА \\ *email: gavrun@list.ru
}

\begin{abstract}
АННОТАЦИЯ Эта статья посвящена обзору наиболее популярных методов оценки степени обонятельных расстройств. Большинство методов оченки степени нарушения обоняния имеют широкий спектр применения для диагностики различных заболеваний, включая психические расстройства, повреждения мозга и нервной системы. Однако, в рамках нашей задачи необходимо рассматривать дисфункиию обоняния в связи с проблемой прохождения воздуха в обонятельньй анализатор человека. Таким образом, в перспективе дальнейших исследований представляется необходимым разработать метод оченки обонятельной функиии на основе параметров дыхания, полученных в результате риноманометричного обследования, что позволит повысить объективность проведенных исследований.
\end{abstract}

Ключевые слова: запах, нос, ольфактометрия, слизь, одорант, дисфункиия, стимул

\section{Introduction}

Method holding fate of studies. I.P. Pavlov

Olfaction plays a major role in our interaction with the environment. The olfactory system not only acts for the detection of potential dangers in the environment, such as smoke, gas or dusts, but also it influences our nutrition, social behavior, and well-being [1]. For human beings, it also has been crucial function for better quality of life. There has been a recent increase in diseases associated with olfactory dysfunction as shown in figure 1 [2]. Moreover, because many patients with olfactory dysfunction have often complained of their olfactory functions as well as reported of chronic pain, olfactory dysfunction must not be neglected anymore. In addition, the olfactory function has been considered to be one of the biological markers associated with various diseases, such as Alzheimer's disease, Parkinson disease, multiple sclerosis, and brain tumor. Thus, the evaluation of olfactory function will shed some light to understand the function of the human olfactory system as well as assess the olfaction value in day-to-day life [2].

The structure of the olfactory analyzer is a complex anatomical and physiological structure. Violation of olfactory function may be due to both, mental disorders and diseases affecting the nervous system, and otorhinolaryngological diseases. 


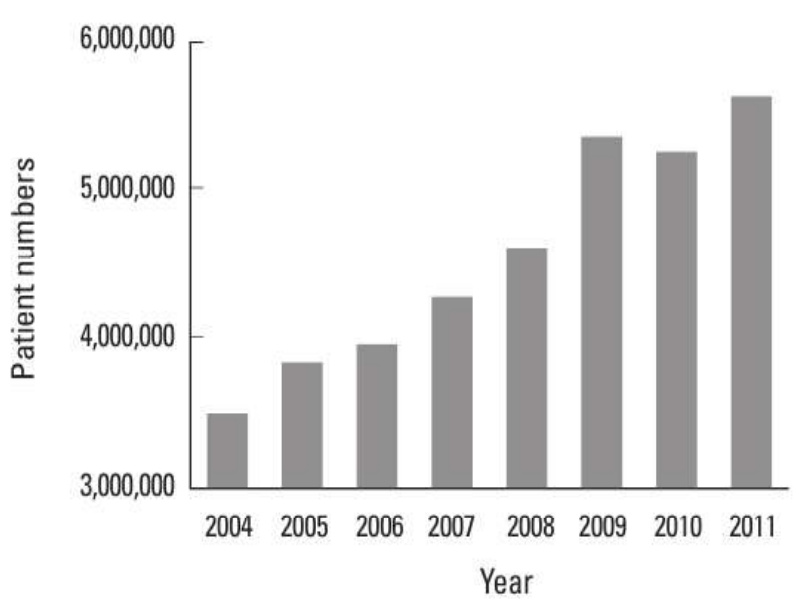

Fig. 1 - Patient trends with olfactory disorders by year [2]

Violations of olfactory function in the broadest sense can be divided into three categories:

- dysfunction of brain regions associated with olfactory information processing;

- disruption of conduction paths (central nervous system), i.e. blocking the signals in the way of the olfactory receptors to the appropriate areas of the brain;

- respiratory-olfactory disorders, blocking of odorants getting into areas of the nasal mucosa, containing olfactory receptors.

It may be necessary a consultation for the patient with various specialists during examination of olfaction neurologists, neurosurgeons, endocrinologists, psychiatrists and others. In particular, it occurs in the situations when the patient with clear violation of smell is no conclusive clinical signs of diseases of the nose and paranasal sinuses [4].

Actuality of the paper.

Violation of olfaction plays an important role in the diagnosis of diseases of the nose and nasal cavity, and it is an indicator of the quality of treatment and postintervention and rehabilitation of patients with various nose injuries as well. Blocking airflow with odorants in the nasal cavity due to various disorders is a very complex problem of modern otorhinolaryngological diagnosis. Today there are no objective methods to assess this problem. Therefore, it is necessary to pay attention to more detailed consideration of objective methods of diagnosis of olfactory dysfunction with a doctor's point of view (otolaryngologist).

\section{Purpose of work}

The purpose is an analytical review of olfactometry of methods and tools to determine their potential and the diagnostic value of the detection of olfactory disorders.

\section{Statement of the main material}

For the overall clinical assessment of the state of the nose the information of state of olfaction, is certainly required. The adequate stimulus for the organ of smell is a variety of molecules of odorous substances (odorants). Smell receptors are presented in the olfactory region, which includes the surface of the mucous membrane of the nasal cavity above the upper nasal turbinates and the opposing part of the nasal septum.

In 1991, Axel and Buck discovered a family of approximately 1,000 genes that encode for an equivalent number of olfactory receptors, corresponding to the largest family of genes in the mammalian genome, highlighting their important role in physiology. In the majority of mammals most of these genes are functional, but in primates the number of functional genes decreases and is only about 350 in humans. Axel and Buck found that each olfactory receptor neuron possesses only one type of odorant receptor and each receptor is specialized for a small number of odors. Hence, a given odorant will bind a typical pattern of olfactory receptors [1].

Recent fundamental studies of the physiological mechanisms of olfaction showed that the process of olfactory reception occurs as follows:

1) olfactory reaction occurs as a result the dissolution odorant molecules in an aqueous-fat medium of membrane, covering the olfactory receptors;

2) each substance in accordance with the theory of matrices, stimulates nerve endings mainly those to which it is closest in meaning their physical and chemical properties, i.e. odor molecule as it is imprinted in its type of olfactory receptor matrix;

3 ) activator of the formation of the smell is nasal mucus;

4) characteristic of smell depends on its adsorption properties;

5) olfactory sensation in a qualitative sense is the result of summation of the olfactory and trigeminal nerves reaction receptor stimulation, which receptors of which are located throughout the surface of nasal mucosa.

The mucous membrane of the respiratory area is lined with ciliated epithelium, cilia movement is "banished" from the nasal cavity mucus and immersed in it dust particles entering from the inhaled air. Oscillation movements of cilia are not directed toward the nostrils, and in the nasopharynx, where shrouded with mucus dust particles or get into the esophagus, or just clear your throat [2].

Purposeful study of olfactory function allows to determine the criteria for the diagnosis of local destruction of various parts of the analyzer.

\section{Discussion of the results}

According to researchers Woo Seop Kim, Dong Pyo Jang, In Young Kim the methods for assessing the olfactory function are largely divided into electrophysiological and psychophysical methods. 
Electrophysiological tests evaluate olfactory function based on objective measurement such as biosignals and medical imaging [3]. For example, the total number of physiological parameters such as galvanic skin response, electrocardiogram data, pneumogram we evaluate olfactory dysfunction [9]. On the basis of physiological parameters there is a method of evaluation of smell, which includes the registration of the background level of pupillary reaction parameters in response to the light signal (pupillography) and in comparison with pupillogramm made after olfactory stimulation by odorants. [10]. The method of estimating the human olfactory activity includes the determination of olfactory function on the results of the subjective assessment of odorous substances in superthreshold solution. It is necessary to provide the registration of background potentials of the brain conduct in a relaxed state at half reclining position of a body examinee with closed eyes in $40 \mathrm{~s}$ after the beginning of registration of the background potentials of the brain.

Using the inhaler Maholda we represent the olfactory stimulus lavender essential oil in a concentration of 1: 100 for 3 seconds and 70 seconds later, the power spectral density is recorded theta and alpha rhythms in the frontal and temporal areas of the cerebral cortex and changes olfactory activity is defined by the formula:

$$
H a=\frac{T_{\theta}+F_{\theta}}{T_{\alpha}+F_{\alpha}},
$$

where $\mathrm{Ha}$ - the olfactory activity;

$T_{\theta}$ - the average value of the theta rhythm of the power spectral density in the temporal region, $\mathrm{mcV}^{2} / \mathrm{Hz}$;

$F_{\theta}$ - the average value of the power spectral density of the theta rhythm in the frontal region, $\mathrm{mcV}^{2} / \mathrm{Hz}$;

$T_{\alpha}$ - the average value of the alpha rhythm of the power spectral density in the temporal region, $\mathrm{mcV}^{2} / \mathrm{Hz}$;

$F_{\alpha}$ - the average value of the alpha rhythm of the power spectral density in frontal region, $\mathrm{mcV}^{2} / \mathrm{Hz}$, wherein at the magnitude of the olfactory activity of 0.7 $\mathrm{cu}$ and more olfactory function is normal, and if the value of 0.6 and less shows the violation of the olfactory function, namely, hyposmia [14].

The psychophysical inspections are methods mostly based on questionnaires or simple apparatus. Normally, the evaluator presents a fragrance and then evaluates subjectively the subject's awareness of smelling [3].

On the basis of subjective feelings and recognize odors the method of the threshold olfactometry has been built. The essence of this method is to use the three olfactory substances, valerian tincture, acetic acid and ammonia. The solution is prepared with intervals of concentrations of olfactory substance by 2-2.5 times (see table 1).
Table 1 - The general scheme of quantitative and qualitative study of olfactory sensitivity

\begin{tabular}{|c|c|c|c|}
\hline $\begin{array}{c}\text { Olfactory } \\
\text { substance } \\
\text { and } \\
\text { consistency } \\
\text { of their use }\end{array}$ & $\begin{array}{l}\text { The } \\
\text { amount } \\
\text { of } \\
\text { solution }\end{array}$ & $\begin{array}{c}\text { The } \\
\text { concentrations } \\
\text { of olfactory } \\
\text { substances, } \%\end{array}$ & $\begin{array}{c}\text { Time } \\
\text { inspection, } \\
\text { sec }\end{array}$ \\
\hline $\begin{array}{l}\text { Tincture of } \\
\text { valerian }\end{array}$ & 8 & $\begin{array}{c}0,005 ; 0,01 ; \\
0,025 ; 0,05 ; \\
0,1 ; 0,25 ; 0,5 ; 1\end{array}$ & $10-20$ \\
\hline Acetic acid & 8 & $\begin{array}{c}0,005 ; 0,01 ; \\
0,025 ; 0,05 ; \\
0,1 ; 0,25 ; 0,5 ; 1\end{array}$ & $10-20$ \\
\hline $\begin{array}{l}\text { Ammonium } \\
\text { chloride }\end{array}$ & 11 & $\begin{array}{c}0,0005 ; 0,001 ; \\
0,0025 ; 0,005 \\
0,01 ; 0,025 ; \\
0,05 ; 0,1 ; 0,25 \\
0,5 ; 1\end{array}$ & $10-20$ \\
\hline
\end{tabular}

Each of the prepared solutions is placed in a glass bottle of glass tubes with volume about $100 \mathrm{ml}$ with cross-sectional area of the neck $0,64 \mathrm{~cm}^{2}$; olfaction research is carried out at room temperature of solutions $18-22^{\circ} \mathrm{C}$ and in the following order: tincture of valerian, acetic acid, ammonium chloride [11].

The next and one of the most popular around the world method for assessing of violations of the olfactory function is Sniffing Sticks test. In the first stage to determine the olfactory threshold n-butanol of 16 solutions is used (orange, leather, cinnamon, peppermint, banana, lemon, licorice, turpentine, garlic, coffee, apple, clove, pineapple, rose, anise, fish). In assessing the ability to discriminate odors odorants triplets are used in superthreshold dilution, while the patient is asked to choose which smell is different from the two other (fig.2) [5].

In determining the subject's ability to identify the smell - the patient is proposed in the superthreshold concentration of the odorant and four possible answers. At each stage of the study the patient can gain a maximum of 16 points, that is, for the time of the study a maximum of 48 points. This index is defined as threshold discrimination identification score (TDI). If TDI patient scores 15 or less, that he is believed to have a functional anosmia. When TDI from 17 to 30 points we conclude the presence of the patient hyposmia. TDI 30 points and above is considered normal [5, 13-14].

The UPSIT comprises forty different smells released by scratching a panel of microencapsulated odorants using a pencil lead. For each of the forty smells, participants must choose an answer from four possible options; only one is correct. Booklets containing the smells, four, each with ten smells, are in sealed envelopes and a pencil provided (fig. 3 ). 


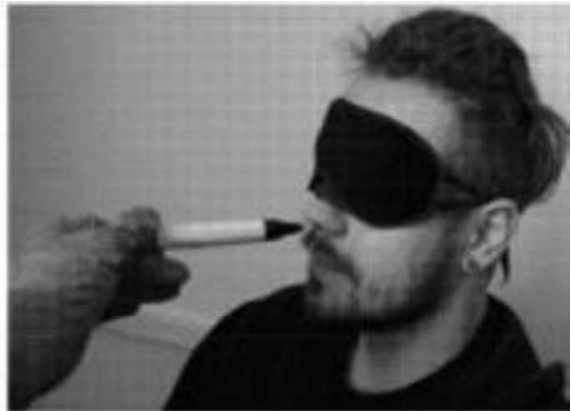

Fig. 2 - Sniffin' Sticks methods in progress [5]

Data collected on the USA population showed that participants' score out of forty was dependent on gender, age and smoking status. A diagnostic ladder was drawn up and six categories devised for olfactory diagnosis depending on score [6]. This test is occasionally judged to have an American cultural bias. There have British, Chinese, French, German, Italian, Korean and Spanish UPSIT versions made. There are called the Brief (CrossCultural) Smell Identification Test. It evaluates olfactory functions uses 12 odor capsules that are familiar with people from other cultures [3]. The advantages of the test are: reliability, low cost, ease of use, the possibility of testing in all conditions, even the self-test at home or in the field.

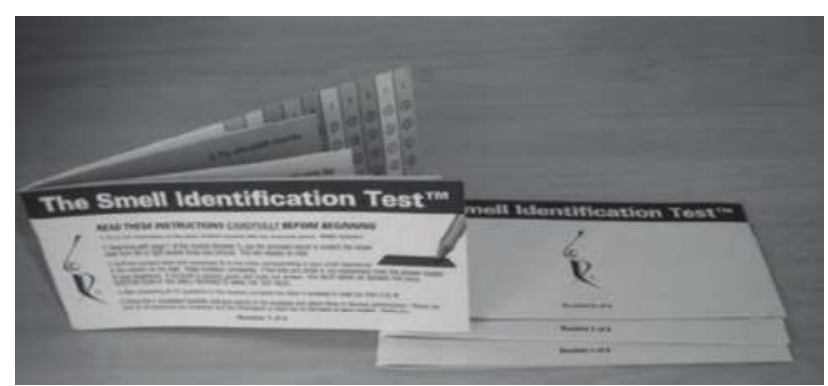

Fig. 3 - University of Pennsylvania Smell Identification Test (UPSIT) [6]

The T\&T olfactometer (Daiichi-Yakuhin, Tokyo, Japan) consists of five test odorants. Each odorant was diluted into eight log-step concentration series with either propylene glycol or liquid paraffin (grade 5 to -2 ). The detection threshold is the weakest concentration at which the stimulus is firstly noticed. The concentration at which a qualitative sensation is first recognized is recorded as the recognition threshold [8].

Also researches developed an olfactory display shown in figure 4. This display uses the technique used in ink-jet printer in order to produce a jet which is broken into droplets from the small hole in the ink tank. The display can set up an ejection head. This head can store three small tanks and one large tank, thus this display can contain 4 kinds of scents maximum.

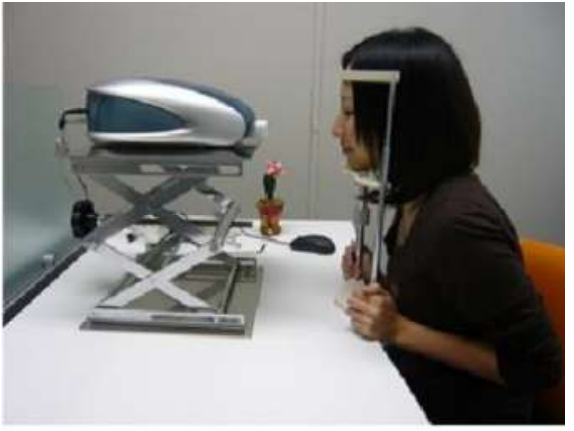

Fig. 4-Olfactory display [7]

Thus, pulse ejection for scent presentation is able to minimize odor elimination. Measurement algorithm uses binary search. Therefore, might measure the detection threshold at 192 levels in total by changing the number of stimul taneous ejections and ejection time. For measurement result, might be able to quantify the detection threshold. Furthermore, only $5 \mathrm{~min}$ is needed to measure the detection thresholds [7].

In this article we are considered the most popular methods for evaluating the degree of olfactory disorders. There are some other methods as well, but in most cases they differ only by odorants, their concentration and the number of repetitions of test studies.

\section{Conclusions}

Various methods and devices (olfactometer) are used to diagnose olfactory analyzer, but they all have a number of drawbacks: the long duration of the study, the use of objective evidence of the subjects, the use of olfactory substances that affect the end of the threefold nerve, determination of olfactory dysfunction or only quantitatively or qualitatively only. There are, most of the methods to evaluate olfactory disorders have a wide range as well of uses for the diagnosis of various diseases, including mental disorders, brain damage, and nervous system. However, within of our problem, olfactory dysfunction is necessary to consider with the problem in connection of the air passage in the human olfactory system. Therefore, it is expedient to develop a highly specialized method of assessing olfactory - respiratory disorders, which would have a high degree of objectivity for use in clinical practice of otolaryngologists. Thus, in the perspective of further research it seems necessary to develop a method of assessment of olfactory function on the basis of respiratory parameters derived from rinomanometry research that will improve the objectivity of conducted researches.

\section{Список литературы}

1 Huart, C. Plasticity of the Human Olfactory System: The Olfactory Bulb / C. Huart, P. Rombaux, T. Hummel // Molecules. - 2013. - № 18, P. 11586-11600; doi:10.3390/molecules180911586. 
2 Морохоев, В. И. Ольфактометрия в клинической практике / В. И. Морохоев // Научно-практический медицинский журнал «Практическая медицина». - 2011. - № 3. - C. 34-36.

3 Kim, W. S. The Current Status of Evaluation Technologies for the Function of Human Olfaction / W. S. Kim, D. P. Jang, In Y. Kim // Hanyang Med Rev. - 2014. - №34, P. 120-124, doi:10.7599/hmr.2014.34.3.120.

4 Avrunin, O. G. Method of expression of certain bacterial microflora mucosa olfactory area / O. G. Avrunin, N. O. Shushlyapina, Y. V. Nosova, W. Surtel, A. Burlibay, M. Zhassandykyzy // Proc. SPIE 9816, Optical Fibers and Their Applications. - 2015. - 98161L (December 18, 2015); doi:10.1117/12.2229074.

5 Barezak, R. Application of the standard Sniffin' Sticks method to the determination Odor Inpectors' olfactory sensitivity in Poland / R. Barezak, I. Sowka, A. Nych, M. Skretowiez, P. Zwozdiak //. Chemical engineering transaction. - 2010. - 23. - P. 13-18, doi:10.3303/CET1023003.

6 Muirhead, N. Is The University Of Pennsylvania Smell Identification Test (UPSIT) Valid for the UK Population? / N. Muirhead, E. Benjamin, H. Saleh // Rila Publications Ltd. The Otorhinolaryngologist. - 2013. - 6(2). - P. 99-103.

7 Fukasawa, A. Olfactory Measurement Method at Health checkup with Olfactory Display using Pulse Ejection / Aya Fukasawa, Kenichi Okada // International Journal of Informatics Society. - 2013. - 5. - P.13-19.

8 Scadding, G. Diagnostic tools in Rhinology EAACI position paper / G. Scadding, P. Hellings, I. Alobid, C. Bachert, W. Fokkens et al. // Clinical and Translational Allergy. - 2011. - 1:2. - P. 1-39.

9 Морохоев, В. И. Обонятельная дисфункция: диагностика и хирургическое лечение / В. И. Морохоев // Вестник оториноларингологии. -1990. - № 6. C. $36-41$.

10 Способ ольфактометрии: пат. 2089093 РФ кл. А61В 5/00, A61B 3/02, A61B 3/10. Морозова С.В.; Ананин В.В.; Кудрин А.Н.; Овчинников Ю.М. - № 95116668/14: Заявл. 28.09.1995: Опубл.: 10.09.1997.

11 Способ проведения пороговой ольфактометрии: пат. 2169364 РФ кл. G01N 33/15, A61B 10/00, A61J 1/06. Домрачев А.А.; Афонькин В.Ю.; Савченков Ю.И.; Амельчугов СП.; Эрлих И.А. - № 99123781/14: Заявл. 10.11.1999: Опубл.: 20.06.2001.

12 Hummel, T. Normative data for the Sniffing sticks 35 including tests of odor identifi cation, odordiscrimination, and olfactory thresholds: an upgrade based on a group of more than 3,000 subjects / T. Hummel, G. Kobal, H. Gudziol, A. Mackay-Sim // Eur Arch Otorhinolaryngol. 2007. - 264. - P. 237-243, doi:10.1007/s00405-006-0173-0.

13 Савватеева, Д. М. Диагностика и лечение обонятельной дисфункции у больных острым риносинуситом / Д. М. Савватеева, А. С. Лопатин // Российская ринология. 2010. - №2. - C. 8-11.

14 Спосіб визначення нюхової активності людини: Патент на корисну модель 84393, А61В 5/0205 Беспалова С.В., Говта М.В., Котлярова І.В., Кузьменко Ю.О. Публікація відомостей про видачу патенту: 25.10.2013, Бюл.№ 20.

\section{Bibliography (transliterated)}

1 Caroline Huart, Philippe Rombaux, Thomas Hummel Plasticity of the Human Olfactory System: The Olfactory
Bulb. Molecules, 2013, 18, 11586-11600; doi:10.3390/molecules 180911586 .

2 Morohoev, V. I. Ol'faktometriya v klinicheskoy praktike [Olfactometery in clinical practice] Nauchno-prakticheskiy meditsinskiy zhurnal "Prakticheskaya meditsina» [Scientific-Practical Medical Journal "Practice of medicine"], 2011, 3, 34-36.

3 Woo Seop Kim, Dong Pyo Jang, In Young Kim. The Current Status of Evaluation Technologies for the Function of Human Olfaction. Hanyang Med Rev, 2014, 34, 120-124, doi:10.7599/hmr.2014.34.3.120.

4 Oleg G. Avrunin, Natalia O. Shushlyapina, Yana V. Nosova, Wojciech Surtel, Aron Burlibay, Maral Zhassandykyzy. Method of expression of certain bacterial microflora mucosa olfactory area. Proc. SPIE 9816, Optical Fibers and Their Applications, 2015, 98161L (December 18, 2015), doi:10.1117/12.2229074.

5 Radoslaw Barezak, Izabela Sowka, Alicja Nych, Maria Skretowiez, Pawel Zwozdiak. Application of the standard Sniffin' Sticks method to the determination Odor Inpectors' olfactory sensitivity in Poland. Chemical engineering transaction, 2010, 23, 13-18, doi:10.3303/CET1023003.

6 Muirhead, N., Benjamin, E., Saleh, H. Is The University Of Pennsylvania Smell Identification Test (UPSIT) Valid for the UK Population? Rila Publications Ltd. The Otorhinolaryngologist, 2013; 6(2), 99-103.

7 Aya Fukasawa, Kenichi Okada. Olfactory Measurement Method at Health checkup with Olfactory Display using Pulse Ejection. International Journal of Informatics Society, 2013, 5, 13-19.

8 Scadding et al. Diagnostic tools in Rhinology EAACI position paper. Clinical and Translational Allergy, 2011, 1:2, 1-39.

9 Morohoev, V. I. Obonyatel'naya disfunktsiya: diagnostika i khirurgicheskoe lechenie [Olfactory dysfunction: diagnosis and surgical treatment]. Vestnik otorinolaringologii [Journal of otorhinolaryngology], 1990, 6, 36-41.

10 Sposob ol'faktometrii [Method olfactometry]: pat. 2089093. A61B 5/00, A61B 3/02, A61B 3/10. Morozova, N.E., Ananyin, V.V., Kudrin, A.N., Ovchinnikov, Y.M. - № 95116668/14: Stated 28.09.1995: Published: 10.09.1997.

11 Sposob provedeniya porogovoy ol'faktometrii [The method of the threshold olfactometry]: pat. 2169364. G01N 33/15, A61B 10/00, A61J 1/06. Domrachev, A.A., Afonkin, S. Yu., Savchenkov, Y.I., Amelchugov, J.V., Ehrlich, I.A. № 99123781/14: Stated. 10.11.1999: Published: 20.06.2001.

12 Hummel, T., Kobal, G., Gudziol, H., Mackay-Sim, A. Normative data for the Sniffing sticks 35 including tests of odor identifi cation, odordiscrimination, and olfactory thresholds: an upgrade based on a group of more than 3,000 subjects. Eur Arch Otorhinolaryngol, 2007, 264, 237-243, doi:10.1007/s00405-006-0173-0.

13 Savvateeva, D. M., Lopatin, A. S. Diagnostika i lechenie obonyatel'noy disfunktsii u bol'nykh ostrym rinosinusitom [Diagnosis and treatment of olfactory dysfunction in patients with acute]. Rossiyskaya rinologiya [Russian Rhinology], 2010, 2, 8-11.

14 Sposib viznachennya nyukhovoï aktivnosti lyudini [Method of determining the olfactory human activity]: Patent for useful model 84393, A61B 5/0205 Bespalova, S. V., Govta, M. V., Kotljarova, I. V., Kuzmenko Yu. O. Published: 25.10.2013, № 20 . 


\section{About authors (Сведения об авторах)}

Oleg Avrunin- Doctor of Technical Sciences (Ph. D.), Professor, Professor, Department of Biomedical Engineering, Kharkiv National University of Radio Electronics, Kharkiv, Ukraine; e-mail: gavrun@list.ru.

Аврунин Олег Григорьевич - доктор технических наук, профессор, Харьковский национальный университет радиоэлектроники, профессор кафедры биомедицинской инженерии; г. Харьков, Украина; e-mail: gavrun@list.ru.

Natalja Shushlyapina - Candidate of Medical Sciences (Ph. D.), Docent, Associate Professor, Department of Otorhinolaryngology, Kharkiv National Medical University, Kharkiv, Ukraine; e-mail: schusha75@mail.ru.

Шуиляпина Наталья Олеговна - кандидат медицинских наук, доцент, кафедра Оториноларингологии, Харьковский национальный медицинский университет, г. Харьков, Украина; e-mail: schusha75@mail.ru..

Yana Nosova - graduate student, Department of Biomedical Engineering, Kharkiv National University of Radio Electronics, Kharkiv, Ukraine; e-mail: yasanosova@rambler.ru.

Носова Яна Витальевна - аспирант, кафедра биомедицинской инженерии, Харьковский национальный университет радиоэлектроники; г. Харьков, Украина; e-mail: yasanosova@rambler.ru.

Olga Bogdan - senior teacher, Department of Foreign Languages, Kharkiv National University of Radio Electronics, Kharkiv, Ukraine; e-mail: nyav007@gmail.com .

Богдан Ольга Николаевна - старший преподаватель, кафедра иностранных языков, Харьковский национальный университет радиоэлектроники; г. Харьков, Украина; e-mail: nyav007@gmail.com.

Please cite this article as:

Avrunin, O., Shushlyapina, N., Nosova, Y., Bogdan, O. Olfactometry diagnostic at the modern stage. Bulletin of NTU "KhPI". Series: New solutions in modern technologies. - Kharkiv: NTU "KhPI", 2016, 12 (1184), 95-100, doi:10.20998/24134295.2016.12.13.

Пожалуйста ссылайтесь на эту статью следующим образом:

Аврунин, О. Г. Ольфактометрическая диагностика на современном этапе / О. Г. Аврунин, Н. О. Шушляпина, Я. В. Носова, О. Н. Богдан // Вестник НТУ «ХПИ», Серия: Новые решения в современных технологиях. - Харьков: НТУ «ХПИ». - 2016. - № 12 (1184). - С. 95-100. - doi:10.20998/2413-4295.2016.12.13.

Будь ласка посилайтесь на ию статтю наступним чином:

Аврунін, О. Г. Ольфактометрична діагностика на сучасному етапі / О. Г. Аврунін, Н. О. Шушляпіна, Я. В. Носова, О. М. Богдан // Вісник НТУ «ХПІ», Серія: Нові рішення в сучасних технологіях. - Харків: НТУ «ХПІ». - 2016. № 12 (1184). - C. 95-100. - doi:10.20998/2413-4295.2016.12.13.

АНОТАЦІЯ Ця стаття присвячена огляду найбільш популярних методів очінки ступеня нюхових розладів. Більшість методів оиінки ступеня порушення нюху мають широкий спектр застосування для діагностики різних захворювань, включаючи психічні розлади, пошкодження мозку і нервової системи. Однак, в рамках нашого завдання необхідно розглядати дисфункцію нюху в зв'язку з проблемою проходження повітря в нюховий аналізатор людини. Таким чином, 6 перспективі подальших досліджень представлясться необхідним розробити метод оцінювання нюхової функиії на основі параметрів дихання, отриманих в результаті риноманометричного обстеження, що дозволить підвищити об'єктивність проведених досліджень.

Ключові слова: запах, ніс, ольфактометрія, слиз, одорант, дисфункиія, стимул 